\title{
Formation of a carcinogenic aromatic amine from an azo dye by human skin bacteria in vitro
}

\author{
T Platzek*,1, C Lang ${ }^{2}$, G Grohmann ${ }^{2}, \mathrm{U}-\mathrm{S} \mathrm{Gi}{ }^{3}$ and W Baltes ${ }^{3}$ \\ ${ }^{1}$ Federal Institute for Health Protection of Consumers and Veterinary Medicine, Postfach 330013, D-14191 Berlin, \\ Germany; ${ }^{2}$ Institute for Microbiology and Genetics, Technical University Berlin, Gustav-Meyer-Allee 25, D-13355 Berlin, \\ Germany; ${ }^{3}$ Institute for Food Chemistry, Technical University Berlin, Gustav-Meyer-Allee 25, D-13355 Berlin, Germany
}

\begin{abstract}
Azo dyes represent the major class of dyestuffs. They are metabolised to the corresponding amines by liver enzymes and the intestinal microflora following incorporation by both experimental animals and humans. For safety evaluation of the dermal exposure of consumers to azo dyes from wearing coloured textiles, a possible cleavage of azo dyes by the skin microflora should be considered since, in contrast to many dyes, aromatic amines are easily absorbed by the skin. A method for measuring the ability of human skin flora to reduce azo dyes was established. In a standard experiment, $3 \times 10^{11}$ cells of a culture of Staphylococcus aureus were incubated in synthetic sweat (pH 6.8, final volume $20 \mathrm{~mL}$ ) at $28 \mathrm{C}$ for $24 \mathrm{~h}$ with Direct Blue 14 (C.I. 23850, DB 14). The reaction products were extracted and analysed using HPLC. The reduction product o-tolidine $\left(3,3^{\prime}\right.$-dimethylbenzidine, OT) could indeed be detected showing that the strain used was able
\end{abstract}

\section{Introduction}

Azo colorants are the most important textile colorants which are divided, according to their solubility, into azo dyes (soluble) and azo pigments (insoluble). They are synthesised from arylamines by diazotation and coupling and are characterised by the azo group (R-N=N-R). It is well-known that soluble azo dyes when incorporated into the body are split into the corresponding aromatic amines by liver enzymes and the intestinal microflora. ${ }^{1,2}$ Several aromatic amines are, or are suspected to be, carcinogenic. It has therefore been stated that 'all azo colorants whose metabolism can liberate a carcinogenic arylamine are suspected of having carcinogenic potential'. ${ }^{3}$ In Germany, clothing textiles containing azo dyes that may release certain aromatic amines may not be marketed according to the Regulations on Specific Commodities (under the Foods Act). ${ }^{4}$ In the past, azo reductase activity has been reported for the mammalian intestinal microflora and mammalian liver enzymes. ${ }^{1,2}$ An analogous activity of skin bacteria is not known. For

${ }^{*}$ Correspondence: T Platzek

Received 1 February 1999; revised 26 April 1999; accepted 3 May 1999 to metabolise DB 14 to the corresponding aromatic amine. In addition to OT, two further metabolites of DB 14 were detected. Using mass spectrometry they were identified as 3,3'-dimethyl-4-amino-4'-hydroxybiphenyl and $3,3^{\prime}$-dimethyl-4-aminobiphenyl. The ability to cleave azo dyes seems to be widely distributed among human skin bacteria, as, under these in vitro conditions, bacteria isolated from healthy human skin and human skin bacteria from strain collections also exhibited azo reductase activity. Further studies are in progress in order to include additional azo dyes and coloured textiles. At the moment, the meaning of the results with regard to consumer health cannot be finally assessed.

Keywords: azo dyes; skin bacteria; metabolism

safety evaluation of the dermal exposure of consumers to azo dyes from wearing coloured textiles, it is relevant to consider a possible cleavage of azo dyes by the skin microflora since, in contrast to many dyes, aromatic amines are easily absorbed via the skin. ${ }^{5}$

In this study, the capability of human skin bacteria to metabolise azo dyes was investigated by measuring the reduction to the corresponding amines. As model compound Direct Blue 14 (DB 14) was used. DB 14 is a typical member of the group of direct dyes which are defined as water-soluble dyes capable of directly dyeing cellulose fibres. In a review of 1975 its use for dyeing textiles and leather was addressed. ${ }^{6}$ More recent data are not available. A standardised assay was established to determine the reductive capacity of skin bacteria using collections of bacterial strains and freshly isolated ones from healthy human skin.

\section{Materials and methods}

\section{Substances}

Direct Blue 14 (Trypan Blue, C.I. 23850, DB 14) and o-tolidine (3,3'-dimethylbenzidine, OT) were pur- 
chased from Aldrich Inc. Since it was reported that OT is a contaminant of DB 14 the content of OT in DB 14 was investigated using HPLC and was found to be less than 5 p.p.m.

\section{Chemical azo cleavage}

Chemical splitting of the dye was performed according to the official method by reduction with sodium dithionate in a citrate-buffered aqueous solution ( $\mathrm{pH} \mathrm{6)}$ at $70^{\circ} \mathrm{C}$ in a closed vessel. ${ }^{7}$ The amines released in the process of reductive cleavage were transferred to a t-butylmethyl-ether phase by means of liquid-liquid extraction using Extrelut ${ }^{\mathbb{R}} 20$ columns (Merck). The eluate was concentrated to $1 \mathrm{~mL}$ in vacuo. The remaining of the solvent was removed by nitrogen. The residue was redissolved in $500 \mu \mathrm{L}$ methanol and directly analysed by HPLC.

\section{Bacteria}

The following bacterial strains were used (strain numbers are those of VLSF, Institut für Gärungsgewerbe und Biotechnologie, Berlin, FRG): Micrococcus luteus (Mi-0702), Micrococcus roseus (Mi0401), Micrococcus varians (Mi-0503), Staphylococcus aureus (St-0411), Staphylococcus epidermidis (St-0201). Additional strains used were St. aureus DSM 1104, St. epidermis DSM 1798, and St. epidermis DSM 22044. Strain Staphylococcus aureus TU 5-3 (previously designated as St. epidermis) was used to establish the standardised assay. ${ }^{8}$

Skin bacteria isolates were taken from the left bend of the elbow of six healthy individuals. There was a time interval of at least $24 \mathrm{~h}$ between the last washing and the time of collection of bacteria. Bacteria were grown and subcultured on Standard I Agar (Merck, Germany). Morphologically different types of colonies were identified and one colony of each type was randomly picked. Pure cultures were obtained by repeated restreaking. Isolates $\mathrm{A}$ to $\mathrm{E}$ were used in the subsequent assays. The isolates were typed according to Bergey's Manual of Systematic Bacteriology. ${ }^{9}$ Strains were stored on nutrient Agar slopes at $4^{\circ} \mathrm{C}$ or in nutrient broth plus $17 \%$ glycerol at $-70^{\circ} \mathrm{C}$.

\section{Culture conditions}

The strains were grown in a preculture $(20 \mathrm{~mL}$ Standard I broth, Merck No. 7782 ) at $28^{\circ} \mathrm{C}$ for $62 \mathrm{~h}$ on a reciprocal shaker (120 r.p.m.). One $\mathrm{mL}$ of the bacterial solution was inoculated into $120 \mathrm{~mL}$ Standard-I-Medium for the main culture which was incubated at $28^{\circ} \mathrm{C}$ for $48 \mathrm{~h}$. If required, induction was achieved by adding DB $14(1 \mathrm{mg} / \mathrm{mL})$ to the main culture. In a typical experiment about $3 \times 10^{11}$ bacteria (about $400 \mathrm{OD}_{610}$ ) corresponding to $60 \mathrm{~mL}$ grown culture, were used per assay. Cells of the stationary phase ( $48 \mathrm{~h}$ growth) were harvested by centrifugation and resuspended in $20 \mathrm{~mL}$ of freshly prepared sweat simulant. Sweat simulant was prepared by dissolving $0.5 \mathrm{~g}$ L-histidine-monohydrochloride-1-hydrate, $5 \mathrm{~g}$ sodium chloride and $2.2 \mathrm{~g}$ sodium dihydrogenphosphate-2-hydrate in $1 \mathrm{~L}$ distilled water and adjusting the $\mathrm{pH}$ to 6.8 . The dye was added to the bacterial suspension in sweat simulant (7 mg DB 14 in a standard assay) and the mixture was incubated at $28^{\circ} \mathrm{C}$ for $24 \mathrm{~h}$ under shaking (frequency 40 r.p.m.) in a water bath. The reaction was stopped by cooling on ice, the $\mathrm{pH}$ was adjusted to 11 with $10 \mathrm{~N} \mathrm{NaOH}$, and the amines were eluted on Extrelut ${ }^{\circledR}$ colunmns with $4 \times 20 \mathrm{~mL}$ tbutylmethyl-ether. The t-butylmethylether extract was then treated as described above.

\section{HPLC separation}

HPLS separation was achieved using the Beckman System Gold. Stationary phase: LiChrosorb 60 RPselect B $(5 \mu \mathrm{m})$; column: $250 \times 4.6 \mathrm{~mm}, \quad(\mathrm{M} \& \mathrm{~W}$, Berlin, Art.-Nr. 254671005); Eluent 1/2: Methanol LiChrosolv/0.575 g ammonium hydrogenphosphate/L, 0.7 g disodium hydrogenphosphate/L, $\mathrm{pH}$ 6.9; Elution: Eluent 1/eluent $2(60 / 40 \mathrm{~V} / \mathrm{V})$, flow $1.0 \mathrm{~mL} / \mathrm{min}$; oven temperature: $40^{\circ} \mathrm{C}$, injection volume 10 or $50 \mu \mathrm{L}$; Detector: Diode array detector (DAD), wavelengths: $207 \mathrm{~nm}$ and $280 \mathrm{~nm}$.

The detection limit of OT was $29 \mathrm{ng}(136 \mathrm{pmol})$ per chromatographic run (50 $\mu \mathrm{L}$ of $500 \mu \mathrm{L}$ injected) corresponding to $1.4 \mathrm{nmol}$ OT per assay. The recovery rate was determined by adding various amounts of OT to the mixture (sweat simulant with bacteria without DB 14) after the $24 \mathrm{~h}$ incubation period. Depending on the amount added, the recovery rate was 76 to $93 \%$. Under these conditions, the recovery rate from five assay vials containing the same amount of OT $(4.3 \mu \mathrm{g})$ was $88 \pm 4 \%$. Nevertheless, 3,3'-dichlorobenzidine was used as an internal standard in most of the experiments.

\section{Capillary gas chromatography/mass spectrometry} Apparatus: HP 5890A, coupled with Finnigan SSQ; GC-column: J \& W fused silica capillary column DB5; dimension $50 \mathrm{~m} \times 0.32 \mathrm{~mm}$, film thickness $0.1 \mu \mathrm{m}$; injection volume $1 \mu \mathrm{L}$, on column temperature programme: $0^{\circ} \mathrm{C}, 1 \mathrm{~min}, 10^{\circ} \mathrm{C} / \mathrm{min}, 240^{\circ} \mathrm{C}, 3^{\circ} \mathrm{C} /$ min, $290^{\circ} \mathrm{C}, 10 \mathrm{~min}$, gas: helium; EI parameter: Transline temperature $280^{\circ} \mathrm{C}$, ion source $150^{\circ} \mathrm{C}$, ionisation energy: $70 \mathrm{eV}$, source pressure ca. $1 \times 10^{-6}$ Torr, cyclic scan $0.9 \mathrm{~s}$, mass area $45-350$; CI parameter: Reactant gas methane, source pressure 7,000 Torr, mass area $80-350$.

\section{Results}

\section{Chemical reduction of $D B 14$}

According to the above-mentioned method DB 14 was reduced with sodium dithionate. The reaction 
products were extracted and isolated as described above. The expected cleavage product OT (see Figure 1) was identified on the basis of the retention time $(7.17 \mathrm{~min})$ and the u.v. spectrum as compared to an authentic standard.

Reaction of DB 14 with St. aureus TU 5-3

Seven mg $(7.3 \mu \mathrm{mol})$ DB 14 was incubated with about $3 \times 10^{11}$ cells of St. aureus TU $5-3$ for $24 \mathrm{~h}$. This strain which had been deposited in the collection as St. epidermidis was chosen as a typical representative of the major class of human skin bacteria. ${ }^{10}$ The strain was reclassified as St. aureus during this study. The reaction products were extracted and isolated as described above. The HPLC separation of the reaction product is shown in Figure 2. In addition to OT, two further u.v.absorbing compounds were detected during HPLC separation (retention times 8.09 and $19.66 \mathrm{~min}$, respectively). No reaction products were seen when DB 14 was incubated in sweat simulant under standard conditions in the absence of bacteria. Likewise reaction products were absent in the bacteria suspension when no azo dye had been included in the reaction mixture.

Similarly, three cleavage products were detected in a total ion current chromatogram by GC/MS analysis of the reaction products (see Figure 3). Using EI- and CI-mass spectrometry, the compound at the HPLC retention time $8.09 \mathrm{~min}$ was identified as 3,3' - dimethyl - 4 - amino - 4'-hydroxybiphenyl (DAHBP) whereas the compound at retention time $19.66 \mathrm{~min}$ was assigned the structure of 3,3'dimethyl-4-aminobiphenyl (DABP) (see Figures 4 and 5).

The CI mass spectrum of DAHBP indicates a molecular mass of 213 and the existence of one nitrogen atom (quasi molecular peaks $\mathrm{M}+\mathrm{H}+=\mathrm{m} / \mathrm{z}$

\section{Direct blue 14}

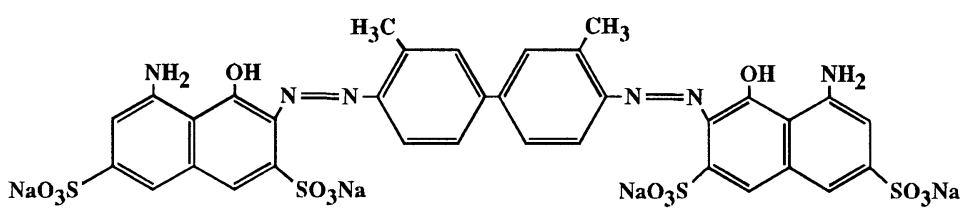

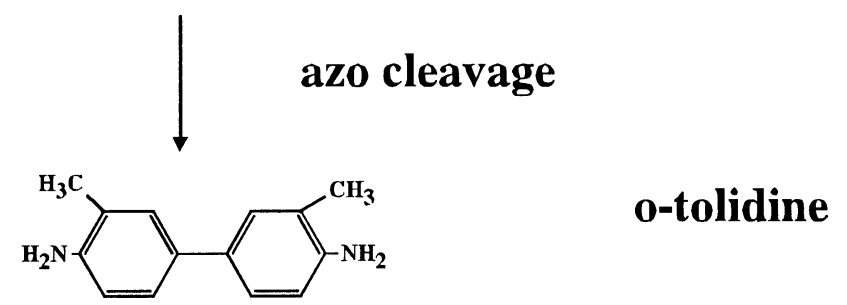

Figure 1 Azo cleavage of DB 14 and formation of OT

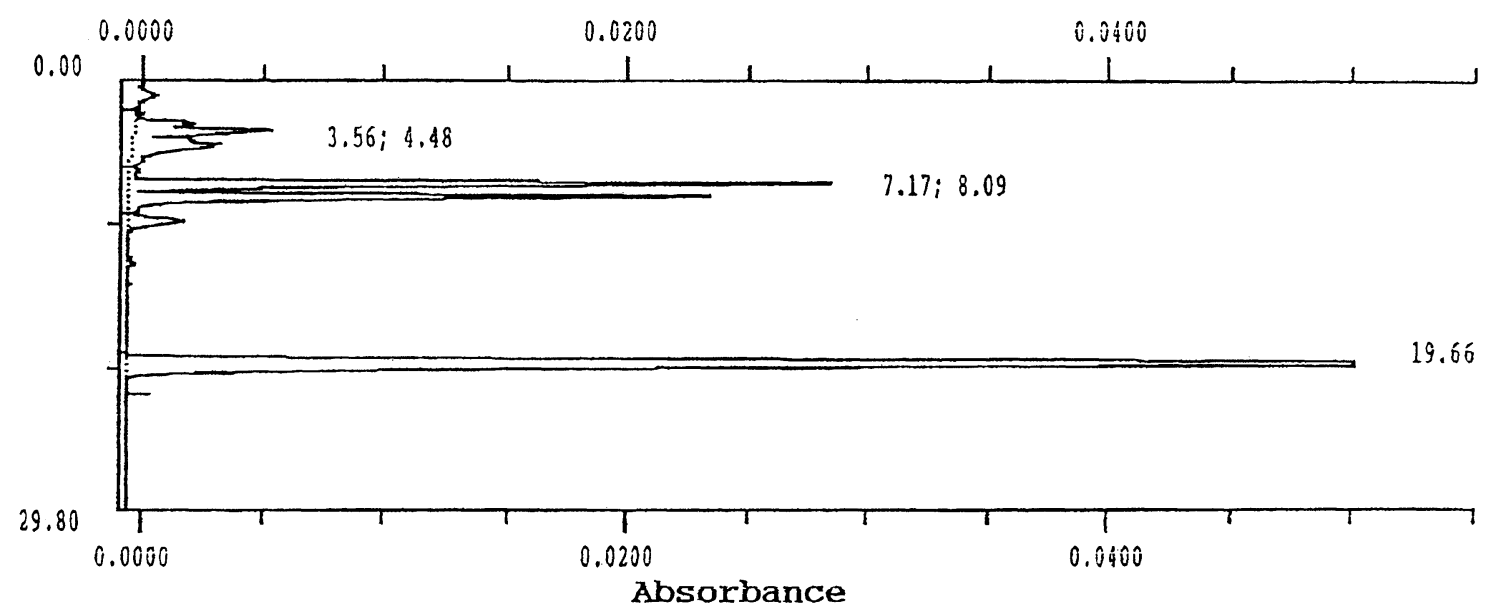

Figure 2 HPLC separation of the reaction product following incubation of DB 14 with St. aureus TU5-3 (standard conditions) 
214; $M+28=m / z$ 242). Furthermore, the difference of $\mathrm{m} / \mathrm{z} 17$ between the fragment ions m/z 169 and m/z 152 may be assigned to a hydroxyl group. This group is additionally indicated by fragments $\mathrm{m} / \mathrm{z}$ 107 and m/z 106 formed by phenyl cleavage. In the case of DABP, the loss of the amino group is indicated by the molecular peak m/z 197.

An additional reaction product was found when the bacteria-dye mixture was incubated under anaerobic and inductive conditions for $72 \mathrm{~h}$ (molecular peak $\mathrm{m} / \mathrm{z}$ 239, quasi molecular peaks: $\mathrm{M}+\mathrm{H}+=\mathrm{m} / \mathrm{z} 240 ; \mathrm{M}+\mathrm{C} 2 \mathrm{H} 4+=\mathrm{m} / \mathrm{z}$ 268). The spectra indicate an $\mathrm{N}$-acetylated derivative, 3,3'-dimethyl4-acetylaminobiphenyl.

\section{Quantitative aspects}

OT as the expected product of the reduction of DB 14 was quantified in the standard assay and in assays using varying experimental parameters (Table 1). Depending on the assay conditions, 3.2 to $26.0 \mu \mathrm{g}$ (15 to $123 \mathrm{nmol}$ ) OT were formed following incubation of either $7 \mathrm{mg}(7.3 \mu \mathrm{mol}) \mathrm{DB}$ 14 which resembles a reduction rate of 0.2 to $1.7 \%$. Inclusion of the azo dye in the culture medium ('inductive conditions') resulted in a slight increase in the reaction product $(+15 \%$ as compared to the standard conditions). A much more significant effect $(+90 \%)$ was seen when the cells were harvested in a different growth phase (late log to early stat phase versus late stat phase under standard conditions). The increase in OT formation using a high cell concentration was non-linear: a 2.6-fold increase in the number of bacterial cells per assay resulted in a 8.1-fold increase in the amount of OT formed (Table 1)

Due to the lack of standards for the metabolites DABP and DAHBP which are by-products in the reaction, the relative amounts of OT, DABP, and DAHBP were quantified based on the peak areas measured in the HPLC analyses (Table 2). The data have shown that the relative amount of OT is dependent on the assay conditions and that the amount of OT formed might not be fully representative of the total metabolic activity of the cells.

\section{DB 14-reductive capacity of normal skin flora}

Additional strains representative of human skin flora or strains freshly isolated from healthy individuals were assayed for their reductive capacity using DB 14 as a substrate. The cells were grown under standard conditions and OT as the primary reaction product was quantified (Table 3). Interestingly, most of the strains analysed exhibited reductive activity and produced the characteristic cleavage product, OT.

\section{Discussion}

Azo dyes are important colorants. More than 2000 of these substances have been synthesised, and about 500 of them are based on carcinogenic aromatic amines. ${ }^{11,12}$ Following incorporation they are metabolised to the corresponding aromatic amines. In the mammalian liver, azo compounds are metabolised by cytosolic and microsomal

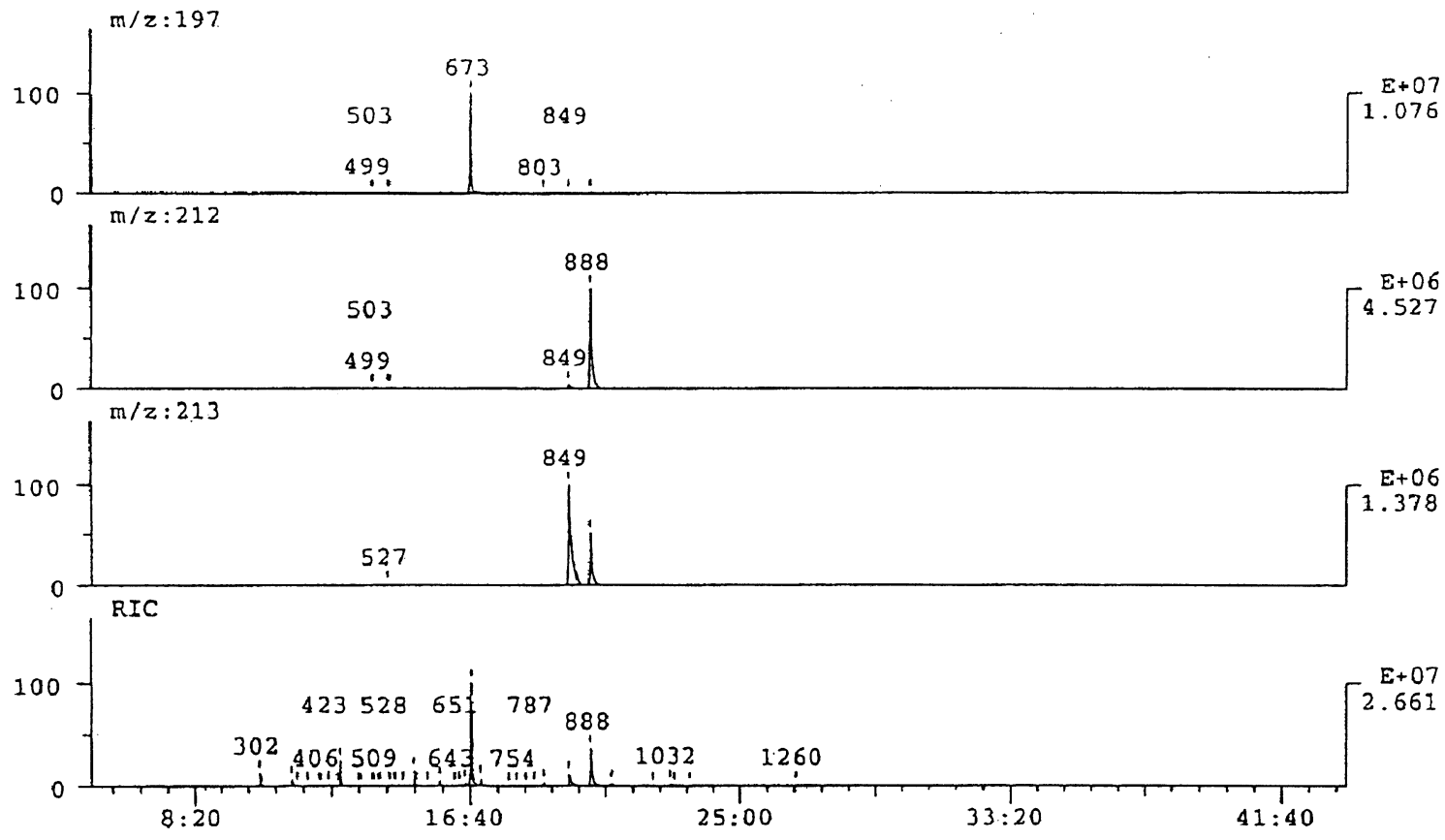

Figure 3 Total ion current chromatogram of GC/MS analysis of the reaction product following incubation of DB 14 with St. aureus TU5-3 (standard conditions) 

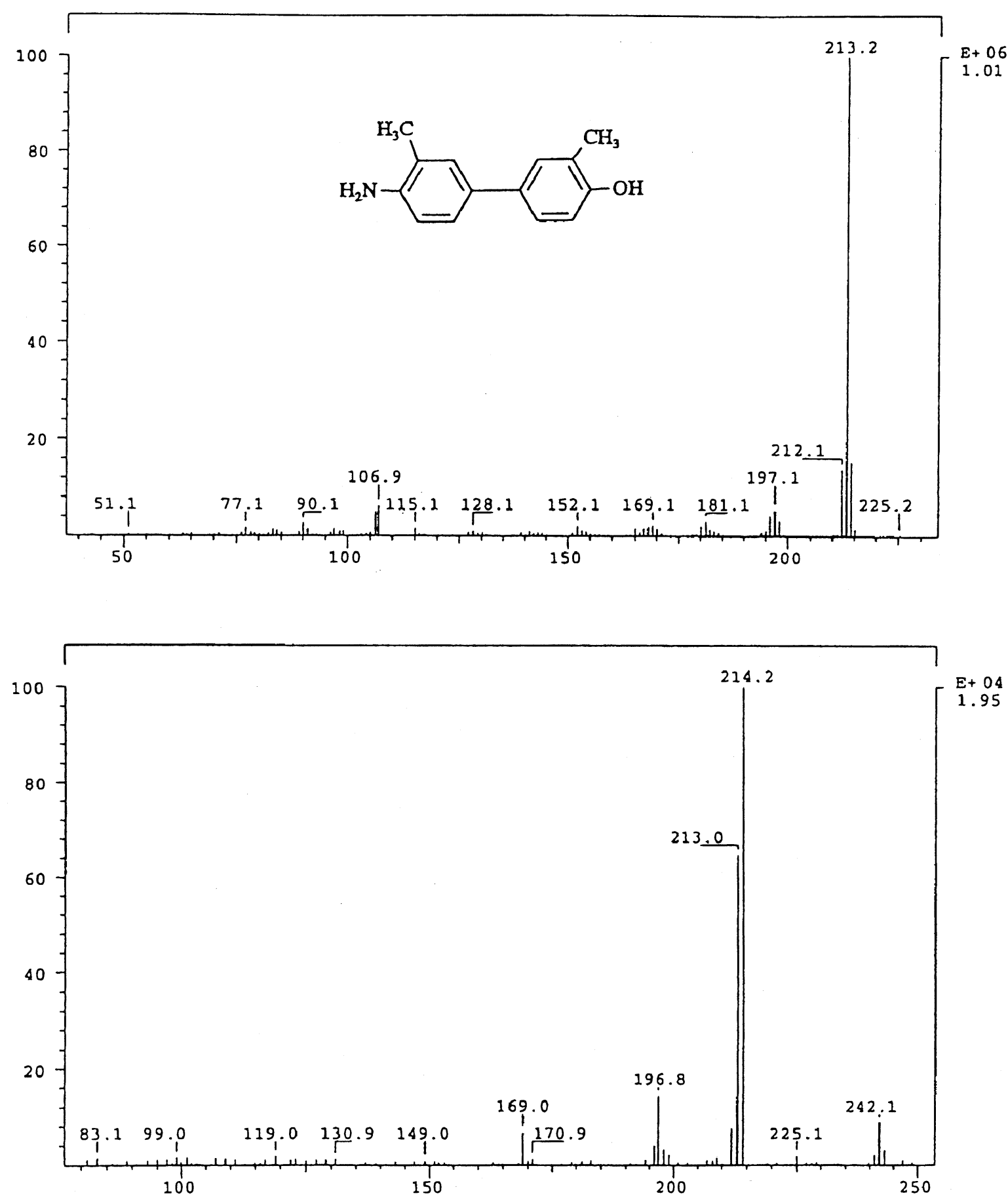

Figure 4 EI and CI mass spectra of DAHBP

enzymes, e.g. by reductive cleavage to the amines. The intestinal microflora plays an even more important role. ${ }^{1,2}$ It was found that bacterial strains in human faeces are capable of cleaving azo dyes. ${ }^{13}$ It has been known for decades that certain azo dyes, which are split into carcinogenic aromatic amines like benzidine, are carcinogenic in both experimental animals and humans. ${ }^{14}$

The mutagenicity of benzidine and benzidinecongener dyes is well documented. A modified
Salmonella assay was developed and DB 14 was found to be mutagenic under these conditions. ${ }^{15,16}$ The significance of azo-reduction in the mutagenesis and carcinogenesis of azo dyes was reviewed earlier. ${ }^{17}$ Additionally, for DB 14 reproductive toxicity is worth mentioning. ${ }^{18}$

The reductive cleavage of azo dyes during percutaneous absorption was investigated in vitro using skin from mice, guinea pigs, and humans. All species tested were capable of reductive cleavage of 

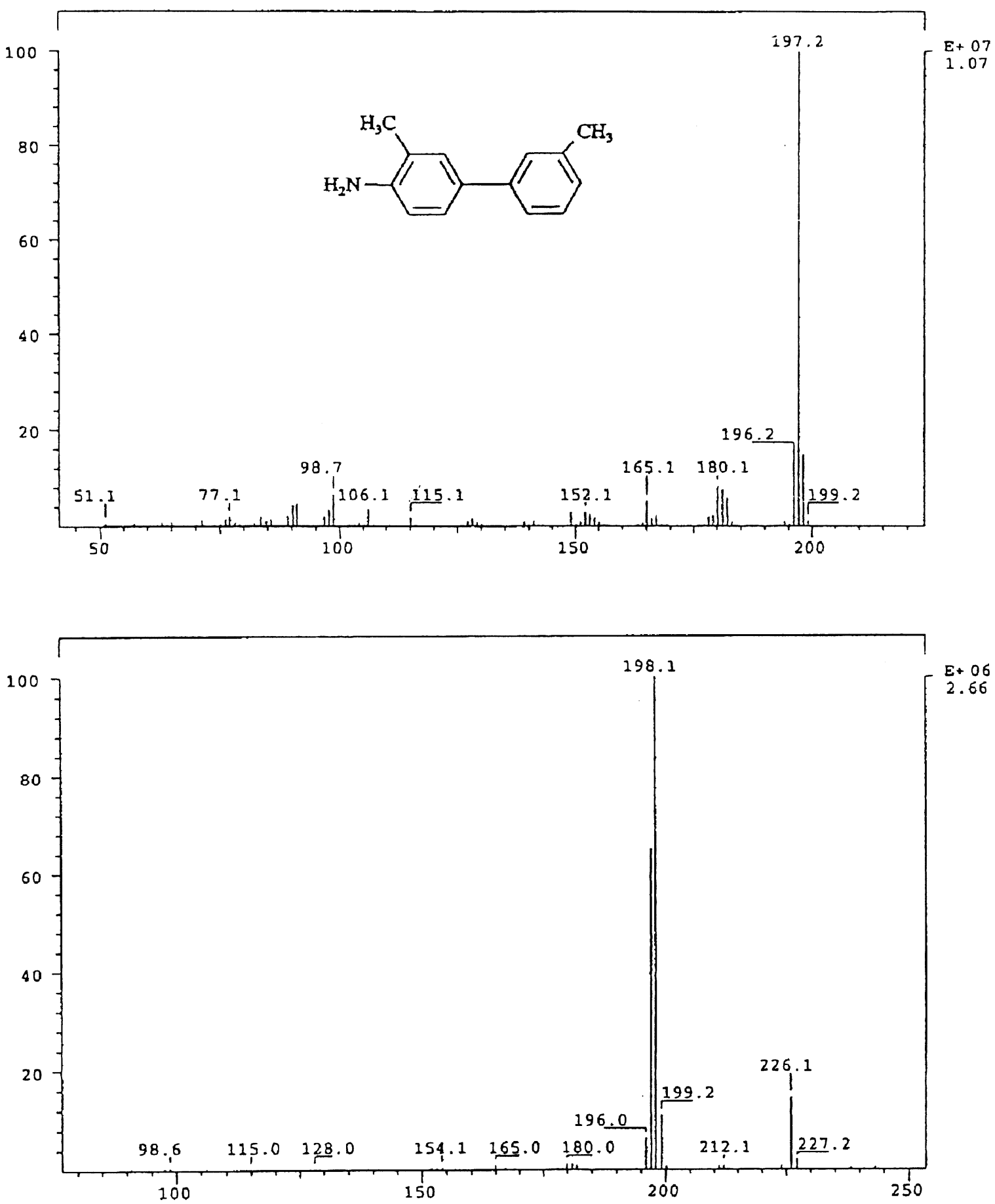

Figure 5 EI and CI mass spectra of DABP

Table 1 Formation of OT after incubation with $S$. aureus TU5-3 cells in sweat simulant ${ }^{\mathrm{a}}$

\begin{tabular}{lc}
\hline Assay condition & OT ( $\mu$ g per assay) \\
\hline Standard assay & 3.2 \\
Standard assay, inductive conditions & 3.7 \\
Cells from early-stationary growth phase & 6.1 \\
Concentrated cell suspension $(2.6 \times)$ & 26.0
\end{tabular}

${ }^{\mathrm{a}}$ Data represent mean values of at least two independent experiments the dyes. ${ }^{19}$ Following epicutaneous treatment of rats in vivo with a ${ }^{14} \mathrm{C}$-labelled azo dye, a significant amount of radioactivity was found in urine and faeces. It was speculated that azo cleavage resulting in the formation of aromatic amines is mediated via the microflora of the rat skin. ${ }^{20}$

The microflora of the human skin is variable with regard to bacterial strains and species. However, staphylococci and micrococci represent major 
Table 2 Relative amounts of OT, DABP, and DAHBP after incubation of DB 14 with St. aureus TU5-3 cells in sweat simulant $^{\mathrm{a}}$

\begin{tabular}{|c|c|c|c|}
\hline Assay condition & $\begin{array}{c}\text { Area } \\
\text { of OT } \\
\text { (relative) }\end{array}$ & $\begin{array}{c}\text { Area of } \\
D A B P \\
\text { (relative) }\end{array}$ & $\begin{array}{c}\text { Area of } \\
\text { DAHBP } \\
\text { (relative) }\end{array}$ \\
\hline Standard assay & $71(1.0)$ & $152(2.1)$ & $91(1.3)$ \\
\hline $\begin{array}{l}\text { Cells from early-stationary } \\
\text { growth phase }\end{array}$ & $159(1.0)$ & $214(1.4)$ & $118(0.7)$ \\
\hline $\begin{array}{l}\text { Concentrated cell suspension } \\
(2.6 \times)\end{array}$ & $390(1.0)$ & $296(0.8)$ & $156(0.4)$ \\
\hline
\end{tabular}

${ }^{a}$ Data from one representative experiment

Table 3 Quantification of OT after incubation of DB 14 with cells of different bacterial strains ${ }^{\mathrm{a}}$

\begin{tabular}{llc}
\hline $\begin{array}{l}\text { Strain/ } \\
\text { Isolate }\end{array}$ & Name & $\begin{array}{r}\text { o-Tolidine } \\
(\mu g / \text { assay) }\end{array}$ \\
\hline St-0201 & Staphylococcus epidermidis & 6.1 \\
St-0411 & Staphylococcus aureus & 10.4 \\
Mi-0702 & Micrococcus luteus & 29.8 \\
Mi-0401 & Micrococcus roseus & 14.8 \\
Mi-0503 & Micrococcus varians & 2.9 \\
DSM 1798 & Staphylococcus epidermidis & 0.0 \\
DSM 22044 & Staphylococcus epidermidis & 6.6 \\
DSM 1104 & Staphylococcus aureus & 0.0 \\
Isolate A & Micrococcus spec. & 6.4 \\
(yellow I) & Coagulase-negative & $13.1^{\mathrm{b}}$ \\
Isolate B & Staphylococcus spec. & $0.4^{\mathrm{b}}$ \\
(white) & Coagulase-negative & $0.5^{\mathrm{a}}$ \\
Isolate C & Micrococcus spec. & \\
(beige) & Coagulase-negative & 0.6 \\
Isolate D & n.d. & \\
(orange) & Coagulase-negative & 0.0 \\
Isolate E & n.d. & \\
(yellow II) & Coagulase-negative &
\end{tabular}

${ }^{a}$ Data represent mean values of at least two independent experiments; 'grown under inductive conditions

groups of bacteria inhabiting the human skin. The quantity varies extremely depending on age and site $\left(6 \times 10^{2} \text { to } 2 \times 10^{6} \text { per } \mathrm{cm}^{2}\right)^{9,21}$

In our experiments using skin bacteria, cleavage of the azo dye DB 14 to the corresponding aromatic amine OT was proved. Following incubation using standard conditions $(24 \mathrm{~h}$ incubation period), further metabolites were detected and identified as deaminated (DABP) and deaminated/hydroxylated (DAHBP) derivatives of OT, respectively. An addi-

\section{References}

1 Levine WG. Metabolism of azo dyes: Implication for detoxification and activation. Drug Metab Rev 1991; 23: $253-309$.

2 Chung K-T, Stevens SE, Cerniglia CE. The reduction of azo dyes by the intestinal microflora. Critical Rev Microbiol 1992; 18: $175-190$. tional reaction product was found following an incubation period of $72 \mathrm{~h}$ which was identified as a deaminated/N-acetylated derivative of OT. Similar microbially-produced metabolites (deaminated and $\mathrm{N}$-acetylated derivatives) were found by Manning et al. following incubation of a culture derived from human faeces with the benzidine-based azo dye Direct Black 38. The authors demonstrated that the mutagenicity was increased by the human intestinal microflora. ${ }^{22,23}$

The wearing of textiles is assumed to be the most widespread exposure to colorants, but the exposure by this route was estimated to be less than $1 \mathrm{mg}$ per individual per day. ${ }^{24}$ The release rate of dyes from coloured textiles was measured, and from these data, the extent of exposure was calculated to be $1-10 \mu \mathrm{g}$ per $\mathrm{kg}$ body weight. ${ }^{25,26}$ However, in the case of garments not having been dyed according to state-of-the-art technology one has to assume much higher release rates and exposures.

Previously, it was argued that, due to the low degree of percutaneous absorption of certain dyes, external exposure to dyes may not pose a significant risk to the consumer. The results of our experiments, however, clearly demonstrate the ability of bacteria of the human skin to metabolise azo dyes to aromatic amines which are known to easily penetrate the skin. In this study, just a small portion of the azo dye present in the assay was split. Presumably, the formation rate is limited by the number of bacteria of the assay and their metabolic capacity. Additional experiments including coloured textiles and lipophilic dyes are in progress to elucidate the quantitative aspects in more detail. It is worth mentioning that, basically, conclusions drawn from in vitro studies to the risk in vivo are of limited value. So far, the risk for the consumer from wearing textiles dyed with such colorants cannot be finally assessed.

\section{Acknowledgements}

Studies were supported by grants from the Forschungszentrum Karlsruhe given to Prof Dr W Baltes. The support of Prof Dr Stahl and Dr Specht, the help of $\mathrm{W}$ Koch with the initial experiments, and the excellent technical assistance of D Wittke are gratefully acknowledged.

3 DFG. Maximum concentrations at the workplace and biological tolerance values for working materials. Report XXIV, Commission for the investigation of health hazards of chemical compounds in the work area. 1988. VCH, Weinheim 
4 Ministry of Health. Regulations on Specific Commodities (Bedarfsgegenständeverordnung). Bundesgesetzblatt I 1998. pp. 6-36.

5 Specht K, Platzek T. Mittel zum Färben und Ausrüsten von Textilien-Anmerkungen zu gesundheitlichen und analytischen Aspekten. Deutsche Lebensmittel-Rundschau 1995; 91: 352 359.

6 WHO. Some aromatic azo compounds. IARC Monograph 1975; 8: $267-278$.

7 BGVV. Vorläufige Methode zum Nachweis der Verwendung verbotener Azofarbstoffe auf gefärbten textilen Gegenständen. Bundesgesundheitsblatt 1966; 39: $78-81$.

8 Platzek T, Gi U-S, Lang C, Baltes W. Azo dyes are split into aromatic amines by human skin bacteria in vitro. Naunyn-Schmiedeberg Arch Pharmacol 1997; 356: (Suppl): R62.

9 Krieg NR, Holt JG. Bergey's Manual of Systematic Bacteriology. 1984. Williams and Wilkins Co., Baltimore.

10 Marples MJ, Charles C. The Ecology of the Human Skin. 1965. Thomas Publisher, Springfield, Illinois.

11 Enquete-Kommission 'Schutz des Menschen und der Umwelt' des 12. Deutschen Bundestages. Die Industriegesellschaft gestalten-Perspektiven für einen nachhaltigen Umgang mit Stoff- und Materialströmen. 1994. Economica, Bonn.

12 Platzek T. Wie groß ist die gesundheitliche Gefährdung durch Textilien wirklich? Melliand Textilberichte 1996; 77: 774-778.

13 Rafii F, Franklin W, Cerniglia CE. Azoreductase activity of anaerobic bacteria isolated from human intestinal microflora. Appl Environ Microbiol 1990; 56: $2146-2151$.

14 Myslak ZW, Bolt HM. Occupational exposure to azo dyes and risk of bladder cancer. $Z b l$ Arbeitsmed 1988; 38: $310-321$.

15 Brown JP, Dietrich PS. Mutagenicity of selected sulfonated azo dyes in the Salmonella/microsome assay: use of aerobic and anaerobic activation procedures. Mutat Res 1983; 116: 305-315.
16 Prival MJ et al. Mutagenicity of benzidine and benzidine-congener dyes and selected monoazo dyes in a modified Salmonella assay. Mutat Res 1984; 136: $33-47$.

17 Chung K-T. The significance of azo-reduction in the mutagenesis and carcinogenesis of azo dyes. Mutat Res 1983; 114: 269-281.

18 Wilson JG. Experimental studies on the mechanism of teratogenic action of trypan blue. J Chronic Dis 1959; 10: $111-130$.

19 Collier SW, Storm JE, Bronnaugh RL. Reduction of azo dyes during in vitro percutaneous absorption. Toxicol Appl Pharmacol 1993; 118: 73-79.

20 Aldrich FD. Excretion of radioactivity from rats and rabbits following cutaneous application of two ${ }^{14} \mathrm{C}$-labeled azo dyes. J Toxicol Environ Health 1986; 18: $347-355$.

21 Kloos WE, Schleifer KH. Isolation and characterisation of staphylococci from human skin: II. Description of four new species: Staphylococcus warneri, Staphylococcus capitis, Staphylococcus hominis, and Staphylococcus simulans. Int J Sys Bacteriol 1975; 25: $62-79$.

22 Manning BW, Cerniglia CE, Federle TW. Metabolism of the benzidine-based azo dye Direct Black 38 by human intestinal mikrobiota. Appl Environ Microbiol 1985; 1: 10-15.

23 Cerniglia CE et al. Mutagenic activation of the benzidine-based dye Direct Black 38 by human intestinal microflora. Mutat Res 1986; 175: 11-16.

24 Anliker R, Steinle D. Verhütung von Risiken beim Gebrauch und bei der Handhabung von Farbmitteln. Textilveredlung 1990; 25: 42-49.

25 ETAD (Ecological and Toxicological Association of the Dyestuffs Manufacturing Industry). Final report on extractability of dyestuffs from textiles. Project A 4007 (1983).

26 ETAD (Ecological and Toxicological Association of the Dyestuffs Manufacturing Industry).

Extractability of dyestuffs from textiles over a normal life time of use. Project G 1033 (1997). 